\title{
УДК: 33.65.005.5
}

Tpym O. O., olgatrut@ukr.net, ORCID ID: 0000-0003-4131-843X, Researcher ID: F-4349-2019,

д.е.н., дои., завідувач кафедри менеджменту, Львівський торговельно-економічний університет, M. Лbвiв

\section{ІНФОРМАЦІЙНО-КОМУНІКАЦЙНИЙ МЕХАНІЗМ РЕАЛІЗАЦІЇ СТРАТЕГІЇ ОРГАНІЗАЦЇ̈}

\begin{abstract}
Анотація. В статті розглянуто складові інформаційно-комунікаџійного механізму як важливого інструменту виконання стратегії організації та підвищення результативності системи менеджменту. Метою статті є уточнення та систематизація науково-теоретичних засад розвитку інформачійно-комунікаційного механізму системи стратегічного управління організаџіями, обтрунтування необхідності впровадження сучасного аналітичного та програмного інструментарію в системи менеджменту вітчизняних організацій та підприємств. Визначено роль інформаџійно-комунікаційного забезпечення у виконанні стратегії організації. Аргументовано застосування зворотного зв'язку з однією петлею під час ієрархічного підходу формування та реалізаиії стратегї організації. Доведено роль і місие постійного зворотного зв'язку з подвійною петлею в інформаційний системі виконання стратегії сучасної організаиії. Стратегічний зворотний зв'язок забезпечує збір інформації про перебіг реалізації стратегї і перевірку гіпотези про взаємозв 'язок стратегічних иілей та ініціатив. Визначено формальні і додаткові неформальні фактори, щуо впливають на інформаційні потоки виконання стратегії організації. Розглянуто методи вдосконалення комунікацій, щзо забезпечують результативність інформаційного обміну у процесі реалізаиї стратегї. Розглянуто технічні прийоми, які впливають на результативність міжособистісних комунікацій в організації. Аргументовано, щзо постійна модифікація комунікативних зв'язків зміцнює взаєморозуміння між працівниками організації $i$ забезпечує результативність стратегії. Визначено роль формальної структури і культури організації у виборі методів поширення інформачії і координащії дій з виконання стратегії організації. Обгрунтовано аналітичний і програмний інструментарій сучасного менеджера для успішної реалізації стратегї̈ організації.
\end{abstract}

Ключові слова: аналітичні засоби, зворотний зв'язок, інформація, комунікації, механізм, організація, система управління, стратегія, програмні засоби.

Trut O.O.,

olgatrut@ukr.net, ORCID ID: 0000-0003-4131-843X,

Researcher ID: F-4349-2019,

Doctor of Economics, Associate Professor, Head of the Department of Management, Lviv University of Trade and Economics, Lviv

\section{INFORMATION-COMMUNICATION MECHANISM OF ORGANIZATION STRATEGY IMPLEMENTATION}

\begin{abstract}
The article considers the components of the information and communication mechanism as an important tool for implementing the strategy of the organization and improving the effectiveness of the management system. The purpose of the article is to systematize and clarify the scientific and theoretical foundations of the informationcommunication mechanism of the strategic management system of organizations, justify the need for modern analytical and software tools in the management systems of domestic organizations and enterprises. The role of informationcommunication support in the implementation of the strategy of the organization is determined. The use of single-loop feedback during the hierarchical approach to the formation and implementation of organizational strategy is argued. The role and place of constant feedback with a double loop in the information system of strategy implementation of a modern organization is proved. Strategic feedback provides information on the implementation of the strategy and testing the hypothesis of the relationship between strategic goals and initiatives. Formal and additional informal factors influencing the information flows of the organization's strategy are identified. Methods of communication improvement that ensure the effectiveness of information exchange in the process of implementing the strategy are considered. Techniques that affect the effectiveness of interpersonal communications in the organization are considered. It is argued that the constant modification of communication links strengthens mutual understanding between employees of the organization and ensures the effectiveness of the strategy. The role of the formal structure and culture of the organization in the choice of methods of dissemination of information and coordination of actions to implement the strategy of the organization is determined. The analytical and software tools of a modern manager for successful implementation of the organization 's strategy are substantiated.
\end{abstract}

Key words: analytical tools, feedback, information, communications, mechanism, organization, management system, strategy, software.

JEL Classification: L15, L29, L86

DOI:https://doi.org/10.36477/2522-1205-2021-62-05 


\section{Herald of Lviv University of Trade and Economics. Economic Sciences. № 62, 2021}

Постановка проблеми. В сучасних умовах глобалізації інформація визнана пріоритетним стратегічним ресурсом постіндустріального суспільства та $\epsilon$ основою системи інформаційного забезпечення менеджменту організації. Сьогодні значно зростає роль інформаційних ресурсів і комунікацій як важливого інструменту реалізації стратегії організації.

Класик теорії менеджменту П. Друкер у праці "Информация, которая действительно нужна руководителю” зазначає: “...3 того моменту, як 3'явилися нові інструменти обробки інформації, ділове співтовариство одночасно і переоцінює, i недооцінює значення інформації для організації. Переоцінка інформаційних технологій привела до того, що ми стали міркувати про створення “електронних бізнес-моделей”, здатних самостійно приймати рішення і навіть взяти на себе основні функції 3 управління бізнесом. Сьогодні ніхто вже не обіцяє, що бізнес-моделі будуть самі приймати управлінські рішення. I поки що, наші можливості 3 обробки інформації реалізовувалися не стільки в управлінні, скільки при вирішенні виробничих завдань" [6, с. 10].

За таких умов якісно нового значення в професійній діяльності вітчизняних менеджерів набуває інформаційно-комунікаційна функція у виконанні стратегії організації та особливо вміння ефективно використовувати інформаційні ресурси та забезпечувати результативні комунікації.

Аналіз останніх досліджень і публікацій. У фаховій літературі зі стратегічного менеджменту достатньо грунтовно висвітлені теоретичні засади і методологічні підходи щодо розробки стратегії організації [1, 7, 11. 12]. Питанню розробки стратегії організації присвячено наукові праці зарубіжних та вітчизняних вчених: I. Ансоффа, Л. Боссиди, О. Віханського, Г. Мінцберга, М. Портера, А. Томпсона, Р. Чарана, О. Гарафонової, І. Ігнатьєвої, Б. Мізюка, 3. Шершньової та iн.

Проте, на думку багатьох дослідників стратегічного менеджменту, ключем до успіху стратегії $€$ iї виконання. Більшість менеджерів краще знають як сформулювати стратегію, ніж як змусити цю стратегію працювати. На думку Лоуренса Дж. Гребін'яка, реалізація стратегії - справа складна, але вона цілком заслуговує уваги керівництва на всіх рівнях управління організацією. Всі менеджери несуть відповідальність за успішне здійснення стратегічних планів. Практичне виконання - це завдання не тільки працівників нижчого рівня управління [3, с. 2-7]

В сучасній економічній літературі зі стратегічного менеджменту науковий пошук напрямів, методів, способів та інструментів механізму виконання стратегії сконцентрували зарубіжні вчені: П. Друкер, У. Кінг, Д. Кліланд, Г. Кокінз, Д. Каплан, Р. Нортон, Л. Дж. Гребін'як. У працях зарубіжних вчених наукові дослідження проблем виконання стратегії організації представлені ширше.
Узагальнюючи результати наукових досліджень сучасних проблем та бар'єрів на шляху реалізації стратегії організації зроблено висновок, що частина їх знаходиться на рівні інформаційнокомунікаційної функції менеджменту. Вченим вдалося виявити певну закономірність - основною причиною невдачі у реалізації стратегії $є$ відсутність культури виконання [2, с. 39].

Постановка завдання. Завданням представленого дослідження $є$ виявлення та систематизація складових інформаційно-комунікаційного механізму виконання стратегії організації.

Виклад основного матеріалу дослідження. Нові можливості збору, організації та обробки інформації, що виникли із появою комп'ютерів, озброїли ділове співтовариство сучасними інструментами управління. Але електронна обробка даних не просто дозволила керівникам компаній краще виконувати колишні завдання, вона змінила саму концепцію компанії і сенс поняття “управління”. Для успішного виконання функцій в майбутньому менеджерам необхідна цілісна інформаційна система, що відповідає стратегії, а не окремі інструменти, які використовуються досі переважно для опису минулих подій [4, с. 63].

Проте в багатьох вітчизняних організаціях досі збереглися системи планування і контролю, побудовані за ієрархічним принципом, які були характерні для індустріальної епохи. Стратегія формулюється на найвищому організаційному рівні, оскільки саме керівники визначають довгострокові цілі й політику організації, а також розміщення ресурсів. Потім менеджери середнього рівня i співробітники організації отримують команду діяти відповідно до цих стратегічних планів. Контроль за правильним використанням ресурсів здійснюють 3 допомогою спеціальної системи менеджменту. На більш низьких ієрархічних рівнях перевіряють операційну діяльність, спрямовану на вирішення короткострокових завдань.

Ієрархічний підхід до формулювання стратегії і шляхів іï реалізації дієвий в тому випадку, коли керівництво організації має чітке уявлення про кінцеві цілі і способи їх досягнення. Такий процес, коли завдання вже визначені і змінюватися не будуть, називається зворотним зв'язком з однією петлею. Відхилення від запланованих показників не викликають у співробітників питання, наскільки ці результати є актуальними зараз. Також їх не цікавить, чи правильні методи отримання встановлених параметрів. Відхилення від обраної траєкторії руху розглядаються як звичайні дефекти, які за допомогою певних дій можна виправити і повернутися до колишнього стану $[7,8]$.

Стратегії сучасних організацій не можуть бути такими прямолінійними i стабільними. Топменеджери потребують зворотного зв'язку для отримання інформації про те, що відбувається в бурхливому світі конкуренції. Стратегія, спланована 3 найкращими мотивами і на основі достовірної в той момент інформації, може швидко застаріти в нових умовах. Аналогічну думку висловлює більшість зарубіжних і вітчизняних вчених. 
Так, на погляд П. Друкера, “...вагомою причиною невдач в бізнесі $€$ впевненість в тому, що зовнішні умови (податки, соціальне законодавство, переваги ринку, канали поширення, права інтелектуальної власності та багато іншого) повинні бути саме такими, якими ми їх собі уявляємо. Або принаймні такими, якими вони, на нашу думку, могли б бути. Адекватна інформаційна система повинна змушувати керівників критично оцінювати свої припущення. Вона повинна не підтверджувати ці припущення, а спонукати менеджерів ставити правильні питання. Передбачається, звичайно, що керівники, по-перше, знають, яка інформація їм потрібна, а по-друге, регулярно іiї отримують i, нарешті, постійно використовують при прийнятті рішень" [6, с. 21].

До інструментарію сучасного менеджера належить діагностична інформація чотирьох видів: базова інформація, інформація про продуктивність, інформація про область спеціалізації та інформація про розподіл ресурсів. Джерела цієї інформації настільки різноманітні, а відбір даних і їх інтерпретація для конкретних цілей настільки складні, що навіть невеликим організаціям потрібна допомога фахівців з інформації. Розглянуті вище чотири види інформації дають уявлення лише про поточний стан бізнесу. На їх основі визначається тактика.

Для вироблення ж стратегії необхідна систематизована інформація про зовнішне середовище компанії. Стратегія повинна грунтуватися на інформації про ринки, споживачів і тих, хто ними не $\epsilon$, про технології у власній та інших галузях, про світові фінанси і про зміни, що відбуваються у світовій економіці. Бо саме у зовнішньому середовищі існують результати. Усередині організації існують тільки центри витрат. Сдиний центр прибутку - це споживач, чек якого оплачений банком. Головні зміни завжди починаються за межами організації [4, с. 32].

Безумовно, менеджмент організації не завжди може отримати всю необхідну інформацію про зовнішнє середовище. Але навіть за наявності необхідної інформації багато організацій не спроможні приділити їй увагу.

Ми поділяємо думку вчених на роль і місце постійного зворотного зв'язку з подвійною петлею в інформаційний системі виконання стратегії організації. Менеджери організації повинні мати можливість користуватися постійним зворотним зв'язком 3 подвійною петлею, тобто отримувати інформацію про те, наскільки створена ними теорія, на підставі якої працює вся організація, відповідає справжнім, можливо, вже умовам, що змінилися. У разі потреби їм доведеться створити нову стратегію, щоб отримати найбільшу вигоду з виниклих можливостей або, навпаки, врахувати всі ризики, які не можна було передбачити на початковій стадії розробки стратегії. Нерідко ідеї про використання нових можливостей лунають із боку лінійних менеджерів.

Звичайно, на практиці обидва погляди на формулювання i реалізацію стратегії, засновані на ієрархічному підході і припущенні про сталий розвиток, співіснують. Співробітники організації щодня вирішують раніше заплановані завдання. Однак кожен учасник цього процесу повинен уважно ставитися до тих нових умов і можливостей (зміни складу споживачів, ринку, технологій і стану суперників), зважаючи на які можна отримати переваги в конкурентній боротьбі. Управління результативністю стратегї має забезпечувати надходження інформації за принципом подвійної петлі - збір даних про впровадження стратегії, перевірка i аналіз iii життєздатності, а також висування новітніх ідей на всіх організаційних рівнях про нові стратегічні можливості та напрями діяльності [8, c. 228-229].

Одним із бар'єрів на шляху реалізації стратегії - брак зворотного зв'язку щодо втілення стратегії в життя і іiі “працездатності". Більшість сучасних систем менеджменту використовує інформацію, отриману зворотним зв'язком, про короткострокові операційні результати, порівнюючи зазвичай реальні фінансові показники 3 місячними і квартальними бюджетами. Аналізу індикаторів реалізації стратегії і факторів успіху приділяється дуже мало уваги, якщо взагалі приділяється.

Вже не раз зазначалося, що “недостатній або неадекватний обмін інформацією між службовцями або підрозділами підприємства, відповідальними за впровадження стратегії, був визначений вченими і практиками-менеджерами як одна 3 головних перешкод на шляху реалізації стратегії.

Опитування менеджерів великих торговельних компаній Західного регіону України, відповідальних за виконання, дозволяють додати: поширення інформації, передача знань і призначені для цього канали комунікації відіграють першочергову роль у процесі реалізації стратегії. Тут, природно, виникає питання про те, що сприяє, а що перешкоджає поширенню інформації, передачі знань та створенню каналів комунікації, необхідних для успішного виконання стратегічних планів. Які чинники впливають на стабільність інформаційних потоків між організаційними одиницями?

Як не дивно це звучить, втім працівники однієї організації, можуть неоднаково трактувати реалізацію іiі стратегії. Вони по-різному бачать перспективу, по-різному визначають ключові терміни, мають неоднакові технічні можливості та культурні переваги. Все це перешкоджає розумінню позиції, яка відрізняється від власної. Селективне сприйняття дійсності, викликане “функціональною короткозорістю" і регіональними відмінностями, стає перешкодою щодо поширення ідей і досягнення взаєморозуміння [3, с.152].

Наше опитування показало, що більшість вітчизняних великих торговельних підприємств зовсім не проводить нарад 3 підведення проміжних підсумків реалізації стратегії. Відповідальність за це несуть віце-президенти з інформаційних технологій та фінансів. В результаті ні власники, ні менеджмент не отримують інформації з питань реалізації стратегії. Оскільки трансформачія стратегії в короткочасні оперативні иілі відіграє найважливішу роль у реалізаиї бізнес-стратегї, така 
трансформачія повинна бути точною $i$ строго контрольованою. Без належного контролю менеджери $i$ прачівники середнього та нижчого рівнів можуть діяти не в тому напрямку, який передбачено бізнес-стратегією. Саме управління результативністю організаиії забезпечує дієвий зворотний зв'язок.

Успішна реалізація стратегії, відповідно до методології управління результативністю, потребує від керівників проведення не лише тактичних операційних нарад, але й стратегічних. Сучасні менеджери вітчизняних організацій повинні усвідомити, як важливо мати своєчасну, адекватну інформацію про перебіг реалізації стратегії.

Стратегічний зворотний зв'язок у системі менеджменту організації характеризується трьома ключовими компонентами:

1. Загальна стратегічна концепція, яка відома всім співробітникам організації і дозволяе кожному 3 них оцінити свій внесок у реалізацію стратегії.

2. Процес зворотного зв'язку, спрямований на збір інформації про реалізацію стратегії і перевірку гіпотези взаємозв'язку стратегічних цілей та ініціатив.

3. Процес вирішення проблем у команді (колективі) на основі аналізу отриманих даних, який дозволяє адаптувати стратегію до нових обставин.

Науковці у галузі інформаційнокомунікаційного менеджменту стверджують, що результативність міжособистісних комунікацій в організації ймовірна за умови усунення міжособистісних бар'єрів: бар'єрів, зумовлених сприйняттям інформації; семантичних бар'єрів; невербальних перешкод; неякісних зворотних зв'язків; невміння слухати й передавати інформацію.

Таким чином для успішної реалізації обраної стратегії абсолютно необхідно, щоб ця стратегія мала зрозумілий і сфокусований характер. Менеджерам треба перевести іiі на мову короткострокових цілей і показників, причому і цілі, і показники повинні бути взаємно погоджені, з метою уникнення проблем, пов'язаних 3 різними поглядами працівників на результат діяльності.

Методи поширення інформації і координації дій багато в чому визначаються формальною структурою i культурою організації. Ці чинники визначають зміст інформації, що передається. Від них залежить, чия думка буде врахована, а чия - ні. Вони визначають відносну значимість координаційних зусиль, встановлюють, в чиєму викладі факти будуть сприйматися 3 довірою, а в чиєму просто проігноровані. Формальна структура і культура організації відіграють важливу роль у багатьох аспектах виконання стратегії.

Додаткові неформальні фактори, що впливають на інформаційні потоки і передання знань, подані у табл. 1.

Вони відображають як інформаційні, так і організаційні аспекти, але, крім того, враховують ефект індивідуальної мотивації до передання знань. Деякі з цих факторів згадуються вперше, інші стосуються речей вже відомих, але всі вони однаково важливі для ефективного поширення інформації.

Підвищенню результативності інформаційного обміну у процесі реалізації стратегії сприяють такі методи вдосконалення комунікацій: регулювання інформаційних потоків, цілеспрямовані управлінські дії, побудова систем зворотного зв'язку та систем збору пропозицій, видання інформаційних бюлетенів, застосування сучасних інформаційних технологій.

Додаткові неформальні фактори

Таблиия 1 (адаптовано джерело [3])

\begin{tabular}{|c|c|c|}
\hline $\begin{array}{l}\text { № } \\
\text { 3/ח }\end{array}$ & Неформальні фактори & Зміст факторів \\
\hline 1 & Характер переданих знань & $\begin{array}{l}\text { • Знання конкретні або знання “приховані" } \\
\text { • Доведена ступінь корисності знань }\end{array}$ \\
\hline 2 & Характер джерела інформації & $\begin{array}{l}\text { - Оцінка джерела і ступеня його достовірності } \\
\text { - Надійність джерела } \\
\text { - Сприйняття мотивації джерела }\end{array}$ \\
\hline 3 & Характер реципієнта інформації & $\begin{array}{l}\text { - Відсутність мотивації } \\
\text { - Недолік “поглинання" } \\
\text { - "Утримувальна здатність" }\end{array}$ \\
\hline 4 & $\begin{array}{l}\text { Характер контексту, в якому } \\
\text { здійснюється передання знань }\end{array}$ & $\begin{array}{l}\text { - Організаційна структура } \\
\text { - Операційна структура } \\
\text { - Система заохочувальних винагород } \\
\text { - Організаційна культура }\end{array}$ \\
\hline
\end{tabular}


У межах системи стратегічного управління організацією лінійним менеджерам варто обирати такі методи вдосконалення комунікацій, які відповідають культурі організації, іiі технічному потенціалу, ступеню важливості стратегічних завдань на певному етапі розвитку. Постійна модифікація комунікативних зв'язків зміцнює взаєморозуміння між працівниками організації і забезпечує їі результативність.

Втім виконанню стратегії організації перешкоджає не тільки комунікаційний механізм, а й інформаційний. Навіть досить освічені менеджери організації, які усвідомлюють потенційну цінність своїх знань про бізнес і активи, часто не готові сприймати іiі 3 економічного погляду. Більшість компаній досі не в змозі добувати необхідну їм інформацію про бізнес; інформація, яку вони отримують, доходить до них недостатньо швидко, відповідно, вже не може братися до уваги. Такі методології, як процесноорієнтоване управління, дають надійне, засноване на фактах уявлення 3 фінансового погляду про витрати виконуваних процесів, їх продуктів, послуг і клієнтів [10, с. 76].

Розглядаючи інформаційну підсистему як підсистему з позицій початкової і динамічної ланки системи стратегічного управління організацією i інформацію як основу для вироблення управлінських рішень, варто підкреслити необхідність і важливість підтримки менеджерами цих елементів системи управління в постійному робочому стані, що, на жаль, не завжди на практиці вдається.

Деякі провідні світові компанії, які усвідомлюють важливість наявної у них інформації, не вміють ефективно витягувати іiі і використовувати, зауважує Г. Кокінз. В результаті процес обміну інформацією між відділами і службами підприємства буває ускладнений. Так, до недавнього часу пошук і витяг необхідної інформації були пов'язані з проблемами відсутності централізованої системи зберігання даних, тому було майже неможливо реалізовувати швидкі рішення, спираючись на програмне забезпечення.

Таким чином, виникла необхідність взаємодії в єдиній мережі всіх комп'ютерів, які є в організації. Ці організації будують свої ІТ-системи на основі неінтегрованих одиночних рішень. Наприклад, сховища даних різних відділів побудовані на різних платформах 3 використанням комбінацій інструментів, частина яких $є$ нестандартними, частина - 3 вичерпаним терміном технічної підтримки, частина побудована на основі інструменту, купленого у постачальника, який більше не працює на ринку [3, c.152]. Застосування поспішних рішень може призвести до того, що супровід програмного забезпечення стане важким. Будь-яка організація досягає моменту, коли стає важливо, щоб комп'ютери могли спілкуватися з іншими комп'ютерами $[10,11]$.

"Недостатньо тільки добути інформацію. Ïї необхідно використовувати для уточнення стратегії компанії, перевірки вихідних передумов і коригування прогнозів”, - зазначає П. Друкер. 3 цією метою можна використовувати нове програмне забезпечення, інформацію, підготовлену на замовлення конкретних груп користувачів. Що нам дійсно потрібно, так це служби, які пропонували б конкретні рекомендації з використання інформації, задавали б конкретні питання, що стосуються компанії-користувача, i, можливо, проводили б інтерактивні консультації. Створення системи збору i обробки зовнішньої інформації можна також доручити стороннім виконавцям. Може, найбільш популярним постачальником таких систем, особливо для невеликих компаній, стане “внутрішній аутсайдер” - незалежний консультант [5, с. 83].

Інновації в технологіях зберігання інформації сьогодні значно випереджають прогрес у розвитку комп'ютерної техніки, знаменуючи собою нову еру, коли створення величезних сховищ інформації стане кращим рішенням для компаній.

Сучасний ринок вимагає готових рішень управління людським капіталом i збалансовану систему показників. Інформація, необхідна для збалансованої системи показників, поповнюється із систем управління базами даних - Oracle Financials, Siebel CRM call center, SAP materials management, PeopleSoft human resources. Зібрати всі ці дані воєдино непросто, оскільки вони взяті з різних базових структур. Прямий доступ до вихідних даних ускладнений у зв'язку з величезною кількістю таблиць (у великих системах їх буває до декількох десятків тисяч). Засоби управління даними, що випускаються постачальниками програмного забезпечення (наприклад, компанією SAS), інтегрують інформацію 3 різних джерел, керуючи внутрішньою логічною моделлю даних і метаданими.

Сучасним менеджерам вітчизняних організацій рекомендуємо в інформаційну підсистему впроваджувати аналітичні програмні додатки, які значно розширюють технічні можливості засобів зберігання і обробки інформації, а саме:

- IT Architecture Planning - багато організацій в кінці 1990-х рр. нехтували цим компонентом у ланцюжку інформації, оскільки боялися “проблеми 2000";

- технологія ETL - технологія виймання, перетворення і завантаження даних;

- інтелектуальне сховище даних надає користувачам масштабовані та гнучкі можливості зберігання інформації;

- $\quad$ бізнес-аналітика (BI) - електронні засоби й інструменти аналізу бізнес-даних. Аналітичні засоби дозволяють підвищити ефективність ведення бізнесу, оперативність і керованість. Цей компонент іноді помилково вважають останнім в інформаційному ланцюжку, адже він використовує ретроспективні дані. Популярною $є$ аналітична обробка в реальному часі (OLAP), що дозволяє оперативно аналізувати дані;

- аналітична звітність - компонент, що здатний ставити питання, пов'язані з прийняттям тих чи інших рішень, аналізувати їх (3 використанням потужних засобів статистичного моделювання) i давати на них відповіді. 


\section{Herald of Lviv University of Trade and Economics. Economic Sciences. № 62, 2021}

Директори 3 інформаційних технологій багатьох компаній вважають метою їх розвитку подальше впровадження автоматизованих технічних засобів у стандартні процеси - управління системою обробки замовлень на постачання або в систему виробництва. Втім, їх погляди є помилковими. Насправді вирішальну роль відіграє адекватне розуміння керівниками і працівниками ситуації, в якій перебуває організація в той чи інший момент. Цьому сприяє використання програмних аналітичних засобів, які допомагають виявляти непомітні тенденції, перевіряти різні гіпотези, оцінювати результати моделювання різних сценаріїв розвитку ситуації і проводити аналіз чутливості $[10$, с. $291-$ 293].

"Програмні аналітичні засоби не змінюють спосіб ведення бізнесу, вони його просто вдосконалюють", зауважує Г. Кокінз. Їх можна розміщувати на всіх рівнях підприємства і застосовувати в повсякденній діяльності, наприклад, в центрі інформаційного обслуговування споживачів, який не тільки забезпечував би клієнтів поточною інформацією, а й пропонував би їм різні рішення. Програмні аналітичні засоби безпосередньо забезпечують користувачів ключовими показниками i спеціалізованою інформацією. Оскільки потреба менеджменту в аналітичних засобах буде зростати, поєднання цього потенціалу з аналітичними додатками може значно збільшити повну вартість інформації, наявної в організації, сприяючи збільшенню продуктивності та рентабельності $[10,11]$.

Основна мета аналітичних додатків - стати невід'ємною частиною роботи менеджерів і персоналу. Проведені численні дослідження впливу бізнес-аналітики на результативність стратегії організації демонструють, що компанії можуть добиватися значної рентабельності інвестицій, використовуючи аналітичні додатки, якщо вони концентрують увагу на актуальних проблемах бізнесу. Програмні аналітичні засоби позитивно впливають на продуктивність працівників розумової праці цілої низки галузей промисловості. Ключем до успішного використання аналітичних додатків $\epsilon$ постійне застосування його результатів, що полягає в прийнятті правильних заходів, які коректують хід виконання стратегії організації.

Висновки i перспективи подальших досліджень у даному напрямі. Для виконання стратегії організації менеджерам необхідна цілісна інформаційна система, яка повинна змушувати їх критично оцінювати свої гіпотези. Вона має не підтверджувати ці припущення, а спонукати менеджерів ставити правильні питання. Дослідженням доведено, що в інформаційний системі виконання стратегії організації визначальним $є$ постійний зворотний зв'язок 3 подвійною петлею. Стратегічний зворотний зв'язок забезпечує збір інформації про перебіг реалізації стратегії і перевірку гіпотези про взаємозв'язок стратегічних цілей та ініціатив.

Причинно-наслідкові зв'язки, що лежать в основі управління результативністю стратегії, дозволяють топ-менеджерам встановити короткострокові завдання, які якнайкраще відображають прогнозовані наслідки від можливих змін показників і факторів їх досягнення.

Сучасне призначення інформації - планування діяльності в майбутньому, інакше кажучи, менеджери сьогодні працюють у напрямку стратегічного інформаційного процесу. Такі можливості менеджерам і надають сьогодні новітні концепції та моделі управління. Концепції управління та інструменти управління залежать одне від одного, зміна одного призводить до зміни іншого.

Доведено, що ефективний стратегічний інформаційний процес складається 3 трьох основних компонентів: загальна стратегічна концепція, зворотний зв'язок, колективне вирішення проблем. Загальне визнання концепції є стартом для стратегічного інформаційного процесу, оскільки в ній сформульовані результати, до досягнення яких прагне організація.

\section{ЛІТЕРАТУРА}

1. Ансофф И. Стратегический менеджмент. Классическое издание / И. Ансофф. - Питер, 2011. -344 c.

2. Боссиди Л. Исполнение. Система достижения целей / Л. Боссиди, Р. Чаран. - М. : Интеллектуальная литература, 2016. - 324 с.

3. Гребін'як Л. Дж. Як змусити працювати вашу стратегію: Ефективна реалізація стратегії та впровадження змін / Л. Дж. Гребін'як; [пер. 3 англ.]. - Дніпропетровськ : Баланс Бізнес Букс, 2006. - 352 c.

4. Друкер П. Эффективное управление / П. Друкер; [пер. с англ.]. - М. : Астрель, 2006. $284 \mathrm{c}$.

5. Друкер П. Эффективное управление. Экономические задачи и оптимальные решения / П. Друкер; [пер. с англ.]. - М. : ФАИР-ПРЕСС, 2001. -288 c.

6. Измерение результативности компании / [пер. с англ.]. - [2-е изд.]. - М. : Альпина Бизнес Букс, 2007. - 220 с. - (Классика Harvard Business review).

7. Каплан Р. Организация, ориентированная на стратегию. Как в новой бизнес-среде преуспевают организации, применяющие сбаланси_рованную систему показателей / Р. Каплан, Д. Нортон; [пер. с англ.]. - М. : Олимп-Бизнес, 2004. $-416 \mathrm{c}$.

8. Каплан Р. Сбалансированная система показателей. От стратегии к действию / Р. Каплан, Д. Нортон; [пер. с англ. М. Павловой]. - [2-е изд., испр. и доп.]. - М. : Олимп-Бизнес, 2014. - 314 с.: ил.

9. Каплан Р. Стратегическое единство: создание синергии организации с помощью сбалансированной системы показателей

Р. Каплан, Д. Нортон. - М. : Вильямс, 2006. - 384 с.

10. Кокинз Г. Управление результативностью. Как преодолеть разрыв между объявленной стратегией и реальными процессами / Г. Кокинз. - М. : Альпина Паблишер, 2015. - 316 с. 
11. Мізюк Б. М. Стратегічне управління : підручник / Б. М. Мізюк. - [2-ге вид., перероб. і доп.]. - Львів : Магнолія-плюс, 2007. - 392 с.

12. Шершньова 3. С. Стратегічне управління : підручник / 3. С. Шершньова. - К .: КНЕУ, 2004. 699 c.

\section{REFERENCES}

1. Ansoff I. Strategicheskij menedzhment. Klassicheskoe izdanie / I. Ansoff. - Piter, 2011. 344 s.

2. Bossidi L. Ispolnenie. Sistema dostizhenija celej / L. Bossidi, R. Charan. - M. : Intellektual'naja literatura, 2016. - $324 \mathrm{~s}$.

3. Hrebin'iak L. Dzh. Yak zmusyty pratsiuvaty vashu stratehiiu: Efektyvna realizatsiia stratehii ta vprovadzhennia zmin / L. Dzh. Hrebin'iak; [per. z anhl.]. - Dnipropetrovs'k : Balans Biznes Buks, 2006. $352 \mathrm{~s}$.

Druker P. Jeffektivnoe upravlenie / P. Druker; [per. s angl.]. - M. : Astrel', 2006. - 284 s.

5. Druker P. Jeffektivnoe upravlenie. Jekonomicheskie zadachi i optimal'nye reshenija / P. Druker; [per. s angl.]. - M. : FAIR-PRESS, 2001. $288 \mathrm{~s}$.

6. Izmerenie rezul'tativnosti kompanii / [per. s angl.]. - [2-e izd.]. - M. : Al'pina Biznes Buks, 2007. 220 s. - (Klassika Harvard Business review).
7. Kaplan R. Organizacija, orientirovannaja na strategiju. Kak $\mathrm{v}$ novoj biznes-srede preuspevajut organizacii, primenjajushhie sbalansirovannuju sistemu pokazatelej / R. Kaplan, D. Norton; [per. s angl.]. M. : Olimp-Biznes, 2004. - 416 s.

8. Kaplan R. Sbalansirovannaja sistema pokazatelej. Ot strategii $\mathrm{k}$ dejstviju / R. Kaplan, D. Norton; [per. s angl. M. Pavlovoj]. - [2-e izd., ispr. i dop.]. - M. : Olimp-Biznes, 2014. - 314 s.: il.

9. Kaplan R. Strategicheskoe edinstvo: sozdanie sinergii organizacii $\mathrm{s}$ pomoshh'ju sbalansirovannoj sistemy pokazatelej / R. Kaplan, D. Norton. - M. : Vil'jams, 2006. - 384 s.

10. Kokinz G. Upravlenie rezul'tativnost'ju. Kak preodolet' razryv mezhdu ob\#javlennoj strategiej i real'nymi processami / G. Kokinz. - M. : Al'pina Pablisher, 2015. - $316 \mathrm{~s}$.

11. Miziuk B. M. Stratehichne upravlinnia : pidruchnyk / B. M. Miziuk. - [2-he vyd., pererob. i dop.]. - L'viv : Mahnoliia-plius, 2007. - $392 \mathrm{~s}$.

12. Shershn'ova Z. Ye. Stratehichne upravlinnia : pidruchnyk / Z. Ye. Shershn'ova. - K .: KNEU, 2004. $699 \mathrm{~s}$.

Стаття надійила до редакиії 30 листопада $2020 \mathrm{p}$. 